\title{
CARLA LOIS (2018), TERRAE INCOGNITAE. MODOS DE PENSAR Y MAPEAR GEOGRAFÍAS DESCONOCIDAS, BUENOS AIRES, EUDEBA, 2018, 283 PP.
}

\author{
Marina Rieznik*
}

En este libro, Carla Lois hace una historia de la aparición en los mapas de tierras que finalmente se mostraron como no existentes; de las imágenes de lo poco explorado y de aquellas de lo nunca visto. El escrito se divide en tres partes, la primera enfoca lo verosímil tomando por objeto la historia de la Quinta Pars o el continente austral que nunca existió; la segunda, centrada en la Patagonia decimonónica, se enfoca en lo poco explorado; la tercera se orienta a develar la construcción del paisaje del abismo de los fondos oceánicos, una historia de la cartografía de lo no visible.

La autora señala que la historia de los saberes geográficos se ha dedicado con fruición a los momentos en que se comprobó la inexistencia de porciones del planeta antes imaginadas; o a las etapas en las que los blancos se fueron llenando en los mapas -asociando estos procesos a funciones políticas, culturales, militares y económicas- y que, por el contrario, muy poco se escribió sobre los momentos previos, de construcción de esos espacios. Lois se pregunta sobre las "condiciones de verosimilitud que dan forma y visibilidad a las geografías desconocidas" (p. 27). Hace un recorrido mostrando que las mutaciones conceptuales que atravesaron las definiciones cartográficas son inseparables de los cambios en la accesibilidad empírica, intelectual y epistemológica a las regiones desconocidas (p. 13; p. 15). La autora propone retomar el planteo de Bruno Latour, cuando intenta especificar en qué situaciones una modificación de las técnicas de inscripción puede introducir alguna diferencia en las formas de argumentar y convencer. En ese sentido, Lois no quiere solo rastrear toponimias de lo descono-

* Instituto de Estudios sobre la Ciencia y la Tecnología, Universidad Nacional de Quilmes (Iesct-unQ); Universidad de Buenos Aires, Conicet. Correo electrónico: $<$ marinarieznik@gmail.com>. 
cido, sino "pensar articuladamente esas estrategias de escritura de lo desconocido atendiendo a sus contextos de producción, sus audiencias, sus relecturas y los intinerarios que siguieron sus transformaciones" (p. 24). Al exponer dichos cambios en sus implicancias políticas, culturales y en sus vinculaciones con formas generales de la visualidad de las diferentes épocas, Lois apela constantemente a registros artísticos y cotidianos.

Acompasando planteos de la historiografía de las cartografías de tierras desconocidas, como las de John Wright o Wilcomb Washburn, con las reflexiones de la filosofía de la representación, como las de Pierre Guenancia, Lois propone al lector aceptar que lo desconocido es algo incierto, pero que "se inscribe en el dominio de lo posible" (p. 25), y que lo contrario a lo posible no es lo imposible, sino la nada y el vacío. Así Lois ofrece una definición de desconocido que no es lo contrario de lo conocido, en tanto sigue siendo algo posible de representar y, en esa construcción, está atado a lo conocido. Después de señalar que "Roland Barthes sugirió que nos hace falta una historia de nuestra propia oscuridad o de la forma en que la idea occidental de conocimiento ha permitido aclimatar nuestro desconocimiento"(p. 32), Lois abre los matices que surgen de considerar a lo desconocido "como una fisura de lo conocido y no como una contracara” (p. 32). Así, un mapa representa no solo geografías empíricas, sino conceptos geográficos que nos ayudan a interpretar geografías no conocidas, sean ellas existentes o inexistentes.

Lois recorre la historia de diferentes operaciones que permitieron definir lo desconocido en el mapa: la escritura y el trazo interrumpido, como una contradicción latente, como señal de la toma de conciencia sobre la falta de conocimiento (p. 72); las líneas rectas o estilizadas para costas o límites hipotéticos (p. 79); la simetría para pensar lo desconocido, como espejando lo ya visto (p. 99). Lois especifica cómo lo espejado no supuso solo una apropiación especular, sino la construcción de un reflejo al modo de aquel en el que se confunden las líneas de lo reflejado con el objeto que se ve con dificultad a través del vidrio (p. 80). Es decir, lo reflejado como hipótesis de trabajo y no como mera ficción (p. 104). Lo verosímil "como una lente que formatea la mirada y, por tanto, la interpretación de la evidencia” (p. 106). En el mismo sentido, afirma que el blanco en el mapa antes que ser un vacío es una acción de vaciamiento (p. 128), que señala distintas cuestiones, políticas y epistemológicas, y que a su vez impulsa acciones cognitivas, con todo el entramado material que la acción de conocer supone, tal como viene mostrando hace algunas décadas la historia de las ciencias. En efecto, este relato se funde con las historiografías de las ciencias que han una y otra vez transitado la relación variable entre verdad, vero- 
similitud, hipótesis y observación a lo largo de la historia. Siguiendo ese ritmo, Lois señala que entidades como el continente austral se fueron esfumando de los mapas, cuando ya lo verosímil no alcanzaba para constituir una hipótesis y se empezaba a exigir que esta esté asociada a protocolos de observación específicos, registros normalizados y determinados modelos explicativos (p. 107). Este camino que siguió la ciencia moderna es el que tuvo que recorrer la imagen de América, que al principio supo ser no más que una enmienda inestable, imprecisa y contradictoria en sus primeras apariciones en la industria del libro del siglo xvi. El blanco, en cambio, siguió un camino inverso, pasó de ser un horizonte a descubrir para convertirse en la marca de un territorio rodeado de lo conocido pero que debía ser explorado con nuevos protocolos de trabajo. Y no obstante, finalmente el blanco pasó a indicar lo que estaba más allá de lo propio, una "deshonrosa cicatriz que recordaba la ignorancia” (p. 170).

Lois señala cómo los blancos desaparecieron de los mapas que se fueron poblando de marcas de civilización: topónimos, grillas de coordenadas, dibujos de proyecciones político-administrativas deseadas. "Cuasi-ficticias" (p. 170), dice la autora respecto de estas líneas político-administrativas trazadas, retomando nociones de Alfred Hiatt (p. 16) y haciendo un guiño a pensar en lo ficticio, lo imaginario y lo desconocido aun en los mapas en los que consiguieron extinguir sus blancos. Lois invita a pensar que toda cartografía, lleve o no el topónimo "terrae incognitae", incluye definiciones de "lo ignorado, lo inexplorado, lo supuesto, lo mal conocido, lo plausible, lo verosímil, lo increíble, lo esperado, lo deseado, lo buscado, lo que está más allá del horizonte (el plus ultra), lo otro, lo diferente, lo proyectado, lo anticipado, lo inconsciente, lo extranjero y la exterioridad" (p. 23).

Y si hay un momento en que se muestra en todo su esplendor la capacidad de la imaginación cartográfica, lo pone de relieve Lois en la tercera parte del libro, al mostrar cómo la cartografía fue desnudando al océano para mapear el fondo marino (p. 171). Entonces la construcción de mapas aparece imbricada con la organización de redes de observadores a lo largo y ancho del planeta, con la introducción de nuevos instrumentos, de registros estandarizados y de convenciones procedimentales que se fueron homogeneizando. Así se fue creando un repertorio visual que contribuyó a que se pueda incluso mapear lo no visible. En este relato queda claro el desarrollo que alcanzó esa cultura visual específica basada en la abstracción durante el siglo xx. Lois señala cómo ese proceso solo se entiende como parte de una historia que concierne también a una vasta serie de imágenes técnicas que, construidas y manipuladas por los practicantes de las ciencias modernas, hicieron visible no solo lo que aparecía inalcanzable al ojo sin 
instrumento, sino -como ya ha marcado William Ivins- hasta fenómenos que solo podrían ser alcanzados por el oído, el gusto o el tacto (p. 199). A pesar de la insistencia con que se ha marcado que la cartografía es un arte mimético que depende de lo que se ve, escribiendo sobre cómo se ha desnudado el mar para mostrar su fondo Lois desnuda también estas pretensiones.

Quiero finalizar esta reseña con un caso de 1967. Entonces dos astrónomos en Cambridge detectaron señales de radio repitiéndose intermitentemente desde el espacio exterior, y lo transformaron en un registro gráfico, era una imagen de señales desconocidas. Luego se sabría que había sido la primera detección de un púlsar, una estrella que emite radiación a intervalos cortos y regulares. Doce años después, esas imágenes recorrieron el mundo en la tapa de un disco de Joy División y llegaron al ámbito de la gráfica publicitaria. Desde entonces circulan adosados en innumerables mercancías, en formatos con los que Walter Benjamin se hubiera hecho un festín. Casualmente o no, el disco de la banda británica fue bautizado Placeres desconocidos. El libro de Lois es un aliento a que los historiadores de las ciencias encontremos en las imágenes técnicas, artísticas y cotidianas las formas de lo desconocido en las ciencias que estudiamos, las imágenes que mostraron lo que después no fue, los modos de imaginar lo que todavía no fue descubierto.

Artículo recibido el 17 de enero de 2020.

Aprobado para su publicación el 27 de febrero de 2020. 